\title{
1 Phylogeny of Paullinia L. (Paullinieae: Sapindaceae), a diverse genus of lianas with rapid \\ 2 fruit evolution
}

4 Joyce G. Chery ${ }^{a^{*}}$, Pedro Acevedo-Rodríguez ${ }^{\mathrm{b}}$, Carl J Rothfels ${ }^{\mathrm{a}}$, Chelsea D. Specht ${ }^{\mathrm{c}}$

5

6 a University Herbarium and Department of Integrative Biology

7 University of California, Berkeley, CA, 94720, USA

9 b Smithsonian National Museum of Natural History, West Loading Dock, 10th and Constitution Avenue, NW, Washington, DC 20560-0166, USA

12 School of Integrative Plant Sciences and L.H. Bailey Hortorium, Cornell University, 13 Ithaca, New York, 14853 USA

*Corresponding author: Joyce G. Chery; joycegchery@gmail.com

\section{Abstract}

Paullinia L. is a genus of c. 220 mostly Neotropical forest-dwelling lianas that displays a wide

21 diversity of fruit morphologies. Paullinia resembles other members of the Paullinieae in being a

22 climber with stipulate compound leaves and paired inflorescence tendrils. However, it is distinct

23 in having capsular fruits with woody, coriaceous, or crustaceous pericarps. While consistent in this

24 basic plan, the pericarps of Paullinia fruits are otherwise highly variable - in some species they

25 are winged, whereas in others they are without wings or covered with spines. With the exception

26 of the water-dispersed indehiscent spiny fruits of some members of Paullinia sect. Castanella, all

27 species are dehiscent, opening their capsules while they are still attached to the branch, to reveal

28 arillate animal-dispersed seeds. Here we present a molecular phylogeny of Paullinia derived from

2911 molecular markers, including nine novel single-copy nuclear markers amplified by 30 microfluidics PCR. This is the first broadly sampled molecular phylogeny for the genus. Paullinia

31 is supported as monophyletic and is sister to Cardiospermum L., which together are sister to 
32 Serjania Mill + Urvillea Kunth. We apply this novel phylogenetic hypothesis to test previous

33 infrageneric classifications and to infer that unwinged fruits represent the ancestral condition, from

34 which there were repeated evolutionary transitions and reversals. However, because the seeds of

35 both winged and unwinged fruits are all dispersed by animals, we conclude that the repeated

36 transitions in fruit morphology may relate to visual display strategies to attract animal dispersers,

37 and do not represent transitions to wind dispersal.

Key words: ancestral state reconstruction, guaraná, microfluidic PCR, single-copy nuclear markers, stochastic character mapping, high-throughput sequencing

\section{Introduction}

Paullinia L. (Paullinieae: Sapindaceae) is a genus of c. 220 lianas native to the Neotropics, with one species ranging from tropical sub-saharan Africa to Zimbabwe (Radlkofer, 1933; Irvine, 1961; Medeiros et al., 2016; Acevedo-Rodríguez and Somner 2018). The Amazon region is the center of diversity of the genus (Medeiros et al., 2016) and contains $44 \%$ of the described species. Members of Paullinia can be identified based on their habit (lianas or vines - seldom erect shrubs), their alternate compound leaves with a terminal leaflet, and their septifragal capsular fruits enclosing arillate seeds. Within this basic morphology there is great variation, particularly in fruit morphology (Radlkofer, 1933, 1895; Acevedo-Rodríguez et al., 2017), degree of leaf dissection, and presence or absence of stems with cambial variants (Bastos et al., 2016; Cunha Neto et al., 2018; Pellissari et al. 2018).

In addition to its taxonomic diversity, morphological disparity, and ecological significance as a prominent component of Neotropical forests (Gentry, 1991), the genus has an extensive history of human utilization. Almost $20 \%$ of Paullinia species are reported to have ethnobotanical uses by the indigenous peoples of Central and South America, primarily as fish poisons, medicines, and

59 caffeine-rich stimulants (Beck, 1990), and stem cross-sections are used in Brazilian marquetry 60 (Tamaio, 2011). The greatest economic impact, however, is from the caffeine-rich seeds of $P$. 61 cupana Kunth, known colloquially as guaraná, which is an important international export 62 commodity for Brazil (Erickson et al., 1984). 
63 What we now recognize as Paullinia was introduced by Plumier (1693) as "Clematis", and 64 subsequently renamed as "Cururu” (Plumier, 1703). Although Plumier (1703) recognized

65 Paullinia (Cururu) to be distinct from the closely related Serjania, Linneaus (1753) included 66 members of Serjania within his concept of Paullinia. Miller (1754) recognized Serjania Mill. as 67 separate from Paullinia, and this treatment was further supported by Schumacher (1794), who 68 called for the recognition of fruit morphology as an "essential character"; Serjania is easily 69 distinguished from Paullinia by its samaroid fruits (rather than capsules). Paullinia and Serjania 70 were placed in section Paullinieae along with Urvillea Kunth and Cardiospermum L. (Kunth 71 1821); this section was later transferred to the rank of tribe by de Candolle (1824) a treatment 72 followed by Radlkofer (1890).

74 More than a century after Paullinia was published, Radlkofer (1895, 1933) reviewed all 91 75 published names and described a total of 148 species. He subdivided the genus into 13 sections 76 based heavily on fruit characters (Table 1, Figure 1), with the first couplet of his Conspectus 77 Sectionum (Radlkofer, 1895, 1933) dividing the genus according to whether the capsules are alate 78 (i.e., winged) or exalate (i.e., without wings; Figure 1 and 2) Finer-scale divisions relied on 79 pericarp morphology and anatomy, inflorescence groupings, number and degree of connation of 80 sepals, and presence of mucilage in leaves (Radlkofer, 1895, 1933). A century later, however, 81 Beck, in his dissertation (1991), concluded that Radlkofer's (1895, 1933) system was unstable and 82 lacking clear structure. He proposed, instead, that Paullinia sensu stricto be reduced to 60 spp., 83 and placed the remaining species into five smaller genera (Beck, 1991). His generic system (Table 84 1) begins by separating taxa based on seed attachment, then by pericarp morphology and venation. 85 The two large genera, Paullinia and Prancea, were organized into sections based on pericarp wing and aril characters, respectively. However, as Beck's (1991) dissertation was never published,

87 Radlkofer's $(1895,1933)$ infrageneric classification remains in effect today.

Until the advent of molecular systematics, which facilitated not only a broad sampling of taxa across the Sapindaceae but allowed testing of proposed affinities based on morphological

91 characters, the monophyly of Paullinieae and the relationships among its genera remained untested. The earliest molecular-based phylogenetic analysis including Sapindaceae (Gadek et al.,

93 1996) did not sample Paullinieae species, but later analyses supported the monophyly of the tribe 
94 (Harrington et al., 2005; Buerki et al., 2009; Buerki et al., 2010) and recovered similar relationships

95 to those inferred from cladistic analyses of vegetative and reproductive characters (Acevedo-

96 Rodríguez, 1993) and a hierarchical analysis of wood anatomy using Ward's clustering algorithm

97 (Klaassen, 1999). Recently, Acevedo-Rodríguez et al. (2017) confirmed the monophyly of

98 Paullinieae (comprising Thinouia, Lophostigma, Urvillea, Cardiospermum, Serjania, and

99 Paullinia) as one of the four successively nested clades within the greater supertribe Paulliniodae.

100 Paullinieae members are united by their climbing habit, stipulate leaves, and paired inflorescence

101 tendrils (de Candolle, 1824; Radlkofer, 1890; Acevedo-Rodríguez et al., 2017), and can be divided

102 into the "Paullinia group" (Urvillea, Cardiospermum, Paullinia) and the "Serjania group"

103 (Serjania, Lophostigma and Thinouia), based on whether their fruit are capsules or samaroid

104 schizocarps (Acevedo-Rodríguez 1993); these groups, however, are not monophyletic (Acevedo-

105 Rodríguez et al., 2017).

106

107 The history of taxonomic confusion surrounding Paullinia and its relatives reveals a lack of

108 macroevolutionary understanding of this lineage, and the reliance on fruit characters highlights the

109 long-standing interest in fruit evolution in the group. However, despite these charismatic features,

110 and the economic and ecological importance of the genus, we still lack a robust phylogenetic

111 framework for Paullinia. In this study, we aim to 1) infer the first broadly sampled molecular

112 phylogeny of Paullinia; 2) explore taxonomic implications of this phylogeny, and; 3) infer the

113 patterns of fruit evolution within the genus. Specifically, the diversity of fruit morphologies-

114 dehiscent winged and unwinged capsules, and indehiscent fruits with echinate pericarps - are

115 hypothesized to be adaptive features aiding in dispersal (Acevedo-Rodríguez et al., 2017); this

116 Paullinia phylogeny allows the reconstruction of transitions among these fruit morphologies and

117 an exploration of their dispersal implications in this species-rich Neotropical genus.

119 Glossary: Alate $=$ winged $;$ Exalate $=$ without wings $;$ Echinate $=$ spiny protrusions on pericarp layer

\section{2. Materials and Methods}


126 Primers for single-copy nuclear markers were designed using the Chery et al. (2017) bioinformatic

127 pipeline, selecting for introns (estimated 500-1100bp) and exons (estimated 400-500bp) by

128 utilizing publicly available Sapindales genomic resources: the Citrus sinensis v1.0 genome and the

129 Dimocarpus longan transcriptome (Lai and Lin, 2013) (scripts available on

130 github.com/joycecheryPaullinia_Phylogeny). Primers were designed in Primer3 (Koressaar and

131 Remm, 2007; Untergasser et al. 2012) with an optimal Tm of $57^{\circ} \mathrm{C}$ using the SantaLucia (1998)

132 calculator. These primer pairs were modified by addition of conserved sequence tags for 133 amplification on Fluidigm Access Array (Fluidigm San Francisco, California, USA). Chloroplast

134 primers were taken from Demesure et al. (1995), Fazekas et al. (2008), and Taberlet et al. (1991).

135 In total, 87 primer pairs were tested, targeting a total of 50 single-copy nuclear exons, 24 single-

136 copy nuclear introns (including nine from Chery et al. 2017), and 13 previously published

137 chloroplast markers. Primers were ordered through Eurofins MWG Operon, LLC (Huntsville

138 Alabama, USA). Two modifications to the Fluidigm protocol (Fluidigm PN 100-3770 J1, San

139 Francisco, California, USA) were carried out to enhance amplification success: annealing

140 temperature of $57^{\circ} \mathrm{C}$ rather than $60^{\circ} \mathrm{C}$ and use of Phire Hot Start II DNA Polymerase reagents

141 (ThermoFisher Scientific, Pittsburgh, Pennsylvania, USA) rather than the

142 FastStart $^{\mathrm{TM}}$ High Fidelity PCR System, dNTPack (Millipore Sigma, St. Louis, Missouri, USA).

\subsection{Sampling Scheme, DNA Extraction}

146 Taxon sampling prioritized testing Radlkofer's classification $(1895,1933)$ and spanning the 147 morphological variation in Paullinia, while taking advantage of available silica-dried leaf material, 148 which yield the highest quality DNA extractions. Genomic DNA was extracted from 191 samples 149 (43 herbarium vouchers and 148 silica-dried leaves). CTAB DNA extractions were performed by 150 an Autogen 965 at the Smithsonian Institution Support Center. Extraction quantity was measured 151 by Qubit ${ }^{\mathrm{TM}}$ dsDNA HS Assay Kit (ThermoFisher Scientific, Waltham, Massachusetts, USA) at 152 the UC Berkeley DNA sequencing facility. All extractions were diluted to a maximum of 50ng/ul 153 as recommended by the iBEST Genome Resource Core (Moscow, Idaho). Extraction quality of all 154 samples was tested by PCR amplification of ITS, which was sanger-sequenced on an Applied 155 Biosystems 3730xl DNA analyzer at the UC Berkeley DNA Sequencing Facility. Sanger- 
sequenced reads were trimmed and cleaned in Geneious v.8.0.5 (Biomatters Ltd., Auckland, New Zealand) and aligned using MAFFT local alignment (Katoh and Standley, 2013).

\subsection{Primer Validation}

Primer pairs were tested for amplification in four accessions (Paullinia turbacensis Chery 13, Paullinia sp. Breedlove 72699, Paullinia carpopodea Pace 317, and Paullinia hystrix Acevedo

163 14408) that span the phylogenetic breadth of the genus according to a preliminary ITS phylogeny.

164 Thirty loci that successfully amplified under identical PCR conditions were further pursued. PCR 165 products for these loci were sequenced directly on an ABI 3730x at the Evolutionary Genomics

166 Laboratory at UC Berkeley. Primers were manually removed from sequences and the cleaned reads 167 were aligned using MAFFT (Katoh and Standley, 2013) implemented in Geneious v.8.0.5 168 (Biomatters Ltd., Auckland, New Zealand) to test for sequence variation among taxa. Two of the 169 thirty loci generated two PCR products and were not pursued further. The final set of target loci 170 included four chloroplast markers (Demesure et al., 1995; Fazekas et al., 2008; Taberlet et al., 171 1991), thirteen novel single-copy nuclear exon loci, four novel single-copy nuclear intron markers, 172 and seven intron markers developed by Chery et al. (2017; see Appendix A).

\subsection{Amplification, Sequencing, and Data Processing}

DNA extractions, primers, and PCR reagents were sent to the iBEST Genome Core Facility

177 (Moscow, Idaho) for amplification by microfluidic PCR and Illumina sequencing. Samples were 178 run through a Fluidigm 192.24 chip with the standard protocol except for Phire Hot Start II 179 reagents and annealing $\mathrm{TM}$ of $57^{\circ} \mathrm{C}$. Amplicons were pooled and gel-purified, then run on a 180 fragment analyzer to verify quality. qPCR was performed to determine the quantity of 181 sequenceable libraries, and these were sequenced on $25 \%$ of a MiSeq lane.

183 Illumina Miseq reads were trimmed of reverse primer sequences and demultiplexed by 184 dbcAmplicon (github.com/msettles/dbcAmplicons) by iBEST and additionally cleaned of forward 185 primers and low quality reads with Trimmomatic v.38 (settings: ILLUMINACLIP:TruSeq3-PE186 2.fa (this file was modified to include all primers):2:30:10 LEADING: 3 TRAILING:3 
SLIDINGWINDOW: 4:15 MINLEN: 36; Bolger et al., 2014). Clean reads were processed through the Fluidigm2PURC pipeline (Blischak et al., 2018). This pipeline is specifically tailored to process Illumina data generated from amplicons and accounts for PCR error and Illumina sequencing errors to predict the likely haplotype(s) for each accession at each locus. The first step merges cleaned paired-end reads using FLASH 2 (Magoc and Salzberg, 2011). These merged reads are processed through PURC (Rothfels et al. 2017), which iteratively clusters reads with the USEARCH cluster_fast algorithm (Edgar, 2010), and detects chimeras using UCHIME's USEARCH function (Edgar et al., 2011) to generate sequences of haplotype(s) for each accession at each locus. Finally, a maximum likelihood estimate of the number of haplotypes for each accession at each locus is generated by the crunch cluster script (Blischak et al., 2018). The output of the Fluidigm2PURC analysis is a MUSCLE alignment (Edgar, 2004) of all haplotypes for each locus. To validate the repeatability of inferred haplotypes (Rothfels et al., 2017), three different PURC regimes were run (denominated "A", "B", and "C"), each with four clustering and chimerakilling iterations and a minimum of 10 reads required for a cluster to be retained at each step (corresponding to $\sim 10 \mathrm{x}$ mean coverage). For example, the regime A clustering criteria were .975 , $.995, .995, .995$, meaning that in the first iteration of this regime sequences must be $97.5 \%$ identical in order to be clustered together, and these haplotypes (the consensus sequence of each cluster plus any as-yet unclustered sequences) are then fed into the second iteration requiring $99.5 \%$ identity, followed by two additional iterations of $99.5 \%$ identity each. The following three regimes were implemented: $\mathrm{A}=.975 .995 .995$.995; $\mathrm{B}=$ = 995 .995 995 .975; $\mathrm{C}=.995$.995 .995 .995). For each locus, maximum likelihood gene trees were inferred in RAxML V. 7.2.8 (Stamatakis, 2014) from the output alignment and putative contaminants and paralogs were removed according to the following workflow: 1) if an accession had multiple haplotypes that formed a monophyletic group, one of these sequences was selected at random; 2) if a putative lineage-specific duplication led to two clades that did not share precisely the same set of taxa (due to inadequate sequencing coverage or other factors), all accessions involved in the duplication were removed from that alignment and; 3 ) if two or more accessions had identical sequences in all loci, these were treated as contaminants (one for the other) and removed. All scripts are available at github.com/joycecheryPaullinia_Phylogeny.

\subsection{Phylogenetic Inference}


218 The final concatenated alignment of 11 loci (nine single-copy nuclear markers, plastid $p s b \mathrm{~A}-\operatorname{trn} \mathrm{H}$,

219 and ITS; for accession list see Appendix B) was analyzed by PartitionFinder2 (Lanfear et al., 2016)

220 implemented in CIPRES (Miller et al., 2010) to select the best-fit partitioning scheme and models

221 of evolution for the data (model=mrbayes, linked branch lengths, BIC model selection metric,

222 search algorithm=all). The input to the PartitionFinder2 analysis was the full alignment with each

223 locus designated as its own data subset. A partitioned Bayesian analysis with two runs each of four

224 chains (one cold, three hot; temp=.02) was performed in MrBayes v.3.2.6, sampling every 1000

225 generations for 10 million generations (Ronquist et al., 2012). The analysis converged with a

226 standard deviation of split frequencies $=.008$ and the estimated sample size (ESS) of all parameters

227 exceeded 3000. TreeAnnotator v1.10.4 (Bouckaert et al., 2014) was utilized to generate the

228 maximum clade credibility tree using the post-burnin trees from the combined MrBayes runs

229 (Figure 3, 4, 5).

\subsection{Trait Evolution}

Paullinia fruit morphologies were categorized as alate (Figure 2B, D), exalate (Figure 2A), or echinate (Figure 2C). Fruit morphology was determined by examining the voucher of each accession in the phylogeny if fruits were present and/or voucher images were available on the

237 Smithsonian Institution Herbarium web database (collections.nmnh.si.edu/search/botany/;

238 accessed 27 February 2019). If fruits were absent from the voucher, but species identity was 239 confirmed by phylogenetic results, other vouchers of that same taxon were evaluated to score fruit 240 morphology for that accession. If the original voucher was sterile, we only sampled a single 241 individual of that taxon, fruit type was recorded from the species descriptions if this is described.

242 The fruit morphology of 12 accessions were unknown and thus these tips were dropped from the 243 phylogeny and excluded in all trait evolution analyses.

245 To infer patterns of fruit evolution, we estimated ancestral states and the total number of fruit 246 morphology transitions across the phylogeny. Ancestral states and the number of state changes 247 were estimated and visualized by stochastic character mapping using the best-fit model 248 (=symmetric rates; $\mathrm{p}=.05$ ) along the branches of the Bayesian maximum clade credibility tree 
using the make.simmap function in the phytools package (Revell, 2012) in R (R Core Team, 2018).

250 Topological and branch length uncertainties were accounted for in the estimation of total average

251 fruit transitions by mapping character histories along the branches of 100 randomly sampled trees

252 from the MrBayes (Ronquist et al., 2012) posterior distribution of trees, and the results were

253 summarized using the describe.simmap function in the phytools package (Revell 2012; R Core

254 Team, 2018). All trees in these analyses were first rendered ultrametric with a relaxed clock model, 255 then pruned down to Paullinia tips with fruit morphology data $(=102$; using the chronos and 256 keep.tip functions, respectively) in the APE package in R (Paradis et al. 2004; R Core Team, 2018).

257 Scripts can be found at github.com/joycechery/Paullinia_Phylogeny and results are in Appendix 258 C.

3. Results

\subsection{Target Selection and Primer validation}

DNA extractions ranged from 2.47-50 ug/ul with an average of $26.3 \mathrm{ug} / \mathrm{ul}$ (after diluting all extractions to a maximum of $50 \mathrm{ng} / \mathrm{ul}$ ). Primer validation resulted in 35\% success (30 of the 87 primer pairs amplified successfully in the set of test species). The final set of loci selected for microfluidics PCR was 28: four chloroplast, thirteen single-copy nuclear exons, four novel singlecopy nuclear intron markers, and seven intron markers published in Chery et al. (2017; see Appendix A).

\subsection{Sequencing and Data Processing}

273 The Illumina Miseq (25\% of a lane) generated 6,500,757 reads spanning 17 of the 28 target loci

274 (the remaining 11 loci did not yield sequence). After additional cleaning with Trimmomatic v.38

275 (Bolger et al., 2014), 6,279,352 reads remained. Of the 191 samples, 189 produced reads for at 276 least one locus. Only loci with at least 9\% success rate across all accessions were pursued. This 277 resulted in 10 loci generated by Miseq and the inclusion of all ITS sequences generated by PCR 278 and Sanger sequencing. The inferred sequences generated by each of the three PURC regimes were 279 consistent (as visualized by maximum likelihood gene trees of all regime haplotypes), suggesting 
repeatability of the inferred haplotypes across the regimes. PURC regime A typically inferred haplotypes for more accessions so was preferred for nine of the 10 loci. For the remaining locus, regime A generated excessive haplotypes, so regime $\mathrm{C}$ was preferred. Two loci were too long for the Miseq paired-end reads to overlap and their alignments contain a central region treated as missing data (“?”).

\subsection{Phylogenetic Inference}

The final concatenated alignment contained 148 OTUs, 814 sequences, 1684 parsimonyinformative sites, and 5881 base pairs across nine single-copy nuclear markers (three novel and six from Chery et al. (2017), psbA-trnH, and ITS. The PartitionFinder2 best scheme favored four partitions as follows: partition one (orange1.1g002083m intron9, orange1.1g027952m intron5, orange1.1g009973m intron5, orange1.1g030977m intron1, orange1.1g036770m intron27): HKY + G; partition two (orange1.1g015495m intron8, orange1.1g016982m intron11,psbA-trnH): HKY + G; partition three (orange1.1g022777m intron3, orange 1.1g019384m intron3); and partition four (ITS): GTR+ G. Gene names are adopted from the Citrus sinensis (Rutaceae) v.1.0 genome (Wu et al., 2014) and Chery et al. (2017).

The maximum clade credibility tree (Figure 3,4,5) is well resolved with $75 \%$ of the nodes having $\geq 95 \%$ posterior probability (PP). Rooted with Cupania and Matayba, Allophylus is sister to the Paullinieae. The first diverging lineage of Paullinieae is Thinouia, followed by Lophostigma, which is followed by a Urvillea + Serjania clade that is sister to Cardiospermum + Paullinia .

Within Paullinia, seven clades are described, which roughly correspond to sections sensu Radlkofer (1895, 1931; Figure 3, 4, 5): Clade I (1.0 PP) = sect. Castanella, sect. Caloptilon, sect. Pleurotoechus, and sect. Neurotoechus; Clade II (1.0 PP) = sect. Enourea; Clade III (0.77 PP) = sect. Phygoptilon; Clade IV (0.95 PP) = sect. Pachytoechus; Clade V (1.0 PP) = sect. Pleurotoechus, P. rubiginosa of sect. Diphtherotoechus, P. rufescens of sect. Isoptilon, and P. sphaerocarpa of sect. Enourea; Clade VI (1.0 PP) = sect. Caloptilon; and Clade VII (0.92 PP $)=$ sect. Neurotoechus and P. turbacensis of sect. Xyloptilon. 


\subsection{Trait Evolution}

313 The ancestral Paullinia fruit morphology was reconstructed as exalate (Figure 6), a character that

314 is also found in the sister lineage, Cardiospermum s.s.. Seven fruit transitions are inferred on the 315 maximum clade credibility tree: five transitions from exalate to alate (in Clades I, III, IV, VI, and 316 VII), one transition from exalate to echinate at the base of the sect. Castanella group in Clade I, 317 and one reversal from alate to exalate in Clade VI. The average number of fruit transitions 318 increases to 8.17 after accounting for topological and branch length uncertainties when character 319 histories of 100 randomly selected trees from the posterior distribution were sampled.

4. Discussion

\subsection{Taxonomic Implications}

The utilization of microfluidics PCR and Illumina sequencing facilitated the generation of the first broadly sampled molecular phylogeny for the genus Paullinia. Given the lack of resolution from chloroplast markers for species-level relationships in the genus (Acevedo-Rodríguez et al., 2017;

329 Chery, unpublished), it was necessary to employ rapidly evolving loci in order to generate robust 330 phylogenetic hypotheses to investigate taxonomy and explore morphological evolution. This 331 phylogeny is an improvement from the most recent molecular phylogeny of the Paullinieae, which 332 utilized ITS and the trnL intron, where the relationships between Serjania, Paullinia, and Urvillea 333 were unresolved, and Cardiospermum was not monophyletic (Acevedo-Rodríguez et al., 2017). 334 Given the incomplete sampling of this genus, we were unable to test the monophyly of 335 Cardiospermum.

337 The bulk of Paullinia sections (sensu Radlkofer 1895, 1933; Table 1) were recovered as 338 monophyletic, thus revealing that many of the morphological characters utilized by classical 339 botanists are synapomorphies for clades and thus carry evolutionary signal as well as being useful 340 for field identification. Some lineages are united by fruit morphology while others are united by 341 various combinations of vegetative characters. Although the analysis presents a great improvement 
to our macroevolutionary understanding of Paullina, increased taxon sampling and/or including

343 more molecular markers is needed to confirm infrageneric relationships and to make new

344 infrageneric circumscriptions, therefore a revised classification will not be proposed until these

345 additional data are incorporated.

347 The first diverging lineage of Paullinia, Clade I, contains sect. Castanella, several members of 348 sect. Pleurotoechus, and single species from sect. Neurotoechus and sect. Caloptilon. Clade I is 349 the most diverse in fruit morphology, containing echinate fruits of sect. Castanella, exalate fruits 350 of sect. Neurotoechus and sect. Pleurotoechus, and alate fruits of sect. Caloptilon. Here, there is a 351 clear case of a transition in fruit types between closely related species: $P$. fuscescens and $P$. 352 costaricensis have been described as "difficult to separate vegetatively" (Flora de Nicaragua, 353 accessed on tropicos.org on 11 March 2019), the former with alate fruits and the latter with exalate. 354 All members in this vegetative and reproductively disparate clade display regular stem 355 development (i.e., without cambial variants).

Clade II contains most of sampled sect. Enourea species and P. subrotunda of sect. Neurotoechus).

358 Section Enourea members have exalate fruits, 5-foliate leaves, and simple stem development (they 359 lack cambial variants). Sister to Clade II, Clade III comprises a monophyletic sect. Phygoptilon, 360 except for the inclusion of P. ternata of sect. Caloptilon. Clade III members all have alate fruits 361 and some members have been reported to have successive cambia (Neto et al., 2018). Clade IV consists of a monophyletic sect. Pachytoechus, all with exalate fruit.

364 Clade V comprises half of sampled sect. Pleurotoechus, P. rubiginosa of sect. Diphtherotoechus, 365 P.rufescens of sect. Isoptilon, and P.josecuatrii. Fruit morphology varies from exalate and sharply 366 triangular (P. rubiginosa), to exalate and globose (sect. Pleurotoechus), to alate with large wings 367 (P.rufescens). The group is united by the presence of the phloem wedge cambial variant in most members (Chery, manuscript in prep.).

370 Clade VI houses most of the sampled sect. Caloptilon species. All species in this clade have alate 371 fruits and compound leaves that are 5-foliate and pinnate or highly dissected (e.g., P. glomerulosa).

372 In some lineages within Clade VI, there are transitions in vegetative characters between closely 
related species. For example, the 5-foliate and phloem wedge cambial variant species $P$. baileyi was recovered as sister to the 3-jugate (or ternate-pinnate sensu Croat 1976) and compound-stem species $P$. stipitata.

Clade VII houses most of the sampled sect. Neurotoechus and the only sampled representative of sect. Xyloptilon (P.turbacensis). This clade is united by the presence of ternate or 5-foliate pinnate compound leaves and compound or phloem wedge cambial variants. Embedded within this group is a clade characterized by the presence of cauliflorous inflorescences ( $P$. alata, $P$. exalata, $P$. largifolia). All species in Clade VII have pyriform exalate fruits except $P$. turbacensis of sect. Xyloptilon that has fruits with small wings.

\subsection{Fruit Evolution}

Fruit morphology has been the most important character used to distinguish Paullinia from closely related genera and to identity and place taxa within the genus, however the patterns of evolution of Paullinia fruit have not been previously explored. The ancestral fruit morphology is inferred to be exalate, and seven transitions are inferred on the maximum clade credibility tree: five transitions from exalate to alate, one transition from exalate to echinate, and one reversal from alate to exalate.

392 The repeated gain of wings might suggest transitions from animal to wind dispersal, which would 393 be consistent with wind-dispersed fruits promoting species diversification (e.g., the evolution of 394 schizocarp fruits with high number of carpels correlated with speciation in the eumalvoids, 395 Malvaceae; Areces-Berazain and Ackerman 2017). This conflicts with the long-standing hypothesis that the radiation of angiosperms is due in part to the evolution of animal-dispersed diaspores that facilitate propagules founding new populations where speciation by isolation can occur ( reviewed by Eriksson and Bremer, 1991; but see Herrera, 1989). However, although the differences in fruit morphologies in Paullinia superficially imply shifts in dispersal syndromes,

400 field observations reveal that all Paullinia fruits open and dehisce their seeds while still attached 401 to the branch, with the exception of some members of the "riparia group" (sect. Castanella), which 402 have fruits that are echinate, indehiscent (in at least one species), and water dispersed (Acevedo403 Rodríguez, personal observation). The pericarp of the dehiscent capsules are usually reddish 
404 (Weckerle and Rutishauser, 2005), and open to display three black glossy seeds covered by a fleshy

405 white aril for consumption. The conspicuousness of the color contrast of the pericarp-seed-aril 406 complex against the forest canopy attracts bird dispersers (van der Pijl, 1982; Howe and 407 Smallwood, 2003; Schmidt et al., 2004). Experiments with wild-caught and hand-raised birds 408 demonstrated significant preference for red fruits (Duan et al., 2014). This exact color contrast is 409 also exhibited by the ovuliferous cones of the conifer genus Phyllocladus (Podocarpaceae), which 410 is also bird dispersed (Contreras et al., 2017). If the alate fruits of Paullinia were wind dispersed, 411 we would expect them to not open on the branch, and for there to be no aril, such as in Serjania; 412 however, the seeds of all the dehiscent-capsuled species of Paullinia are arillate. Other animal 413 dispersers such as rodents are reported for P. sphaerocarpa Rich. ex Juss. (Weckerle and 414 Rutishauser, 2005). The stability of the color-contrast and arillate seeds syndrome across the 415 dehiscent species in Paullinia supports the observation that both alate and exalate fruits are animal 416 dispersed, most probably by birds.

418 If the dispersal unit is the arillate seed rather than the entire alate capsule, then it follows that the 419 fruit wings may function as an attractant. For example, perhaps the wings function to increase the 420 size of the fruit, providing a more attractive visual display to dispersers. The mutualistic 421 relationship between Paullinia and birds is heightened in the dry season when most other plants 422 are not producing fruit (Barro Colorado Island, Panama: Croat, 1978; Leigh, 1999). By reaching 423 peak fruiting at this relatively scarce season, birds are most likely to take advantage of this available food resource (Leigh, 1999), facilitating successful dispersal of seeds.

426 Water dispersal may also be important in Paullinia. At least one species, $P$. hystrix of sect. 427 Castanella, has been reported to be water dispersed, containing green echinate capsules with septa 428 that are slightly thickened and consist of spongy tissue that allows the seed to float (Weckerle and 429 Rutishauser, 2005). Additionally, P. sprucei of sect. Castanella is also water dispersed (Acevedo430 Rodriguez personal observation). Another member of this section, $P$. paullinioides, however, has 431 red dehiscent echinate capsules. The dispersal syndrome of other Castanella members is unknown, 432 however the presence of yellow to green capsules (Figure 2C) in several members is notable 433 because they do not display the optimal color/color contrast for bird dispersal (Duan et al., 2014). 
434 Water dispersal has also been observed in the distantly related $P$. clathrata (Weckerle and

435 Rutishauser, 2005).

437 The repeated transitions in fruit morphology across the phylogeny suggest an advantage associated 438 with dispersal, however in the absence of direct field observations of the preferences of birds for 439 alate vs. exalate fruits, and the dispersal success difference between birds vs. water dispersal, this 440 remains an open question.

\section{Conclusions}

445 Here we present the first molecular phylogeny of Paullinia based on a large molecular dataset, 446 consisting of a set of novel rapidly evolving single-copy nuclear markers and two commonly used 447 markers. Paullinia is recovered with high support as monophyletic and sister to Cardiospermum, 448 which together are sister to Serjania + Urvillea. The ancestral condition of fruit morphology in 449 Paullinia is reconstructed as exalate, and at least seven fruit morphology transitions are estimated 450 in the genus. Although it is tempting to ascribe the evolutionary trend of gain of wings to a 451 transition from animal to wind dispersal, the arillate seeds of both alate and exalate fruits are 452 dispersed by animals; therefore, we conclude that the repeated transitions in fruit morphology 453 represent different strategies to enhance visual display to attract a diversity of bird dispersers. 454 Future research confirming precise bird preferences of different Paullinia fruits could uncover the 455 advantages conferred by diverse fruit morphologies.

\section{Funding Sources}

458 This work was supported by a Chancellor's Fellowship (UC Berkeley Graduate Division), a 459 National Science Foundation Graduate Research Fellowship, an NSF Graduate Research 460 Internship Program (GRIP) award, a Smithsonian National Museum of Natural History 461 Predoctoral Fellowship, an American Society of Plant Taxonomist Graduate Research Award, a 462 Society of Systematic Biologists Graduate Student Award, and by the University of California 463 Berkeley College of Natural Resources and the University and Jepson Herbaria. 


\section{Acknowledgements}

Thank you to Morgan Gostel and Daniel New for technical support with the microfluidics PCR run and to Michael May for assistance with the ancestral state estimations. We would also like to acknowledge Gabriel Fox from the Smithsonian Museum Support Center and the Laboratory of Analytical Biology for molecular lab assistance, and those who facilitated J.G.C plant collections; Melissa Cano and Oris Acevedo (Barro Colorado Island, Panama) and Holy Forbes (UC Botanical 472 Gardens).

Declarations of interest: none

\section{References}

Acevedo-Rodríguez, P., 1993. Systematics of Serjania (Sapindaceae). Part I : A revision of Serjania Sect. Platycoccus. Mem. N. Y. Bot. Gard. 67.

Acevedo-Rodríguez, P., Somner, G.V., 2018. New species of Paullinia (Sapindaceae) from continental tropical America. PhytoKeys 114, 95-113.

Acevedo-Rodríguez, P., Wurdack, K.J., Ferrucci, M.S., Johnson, G., Dias, P., Coelho, R.G., Somner, G. V., Steinmann, V.W., Zimmer, E.A., Strong, M.T., 2017. Generic relationships and classification of tribe Paullinieae (Sapindaceae) with a new concept of supertribe

Areces-Berazain, F., Ackerman, J.D., 2017. Diversification and fruit evolution in eumalvoids Paulliniodae. Syst. Bot. 42, 96-114. https://doi.org/10.1600/036364417X694926 
Beaulieu, J.M., Donoghue, M.J., 2013. Fruit evolution and diversification in campanulid angiosperms. Evolution 67, 3132-3144. https://doi.org/10.1111/evo.12180

Beck H.T. 1991. The taxonomy and economic botany of the cultivated guarana and its wild relatives and the generic limits within the Paullinieae (Sapindaceae). PhD Dissertation, City University of New York.

Beck, H.T., 1990. A survey of the useful species of Paullinia. Adv. Econ. Bot. 8, 41-56.

Bolger, A.M., Lohse, M., Usadel, B., 2014. Trimmomatic: A flexible trimmer for Illumina sequence data. Bioinformatics 30, 2114-2120. https://doi.org/10.1093/bioinformatics/btu170

Bouckaert, R., Heled, J., Kühnert, D., Vaughan, T., Wu, C.H., Xie, D., Suchard, M.A., Rambaut, A., Drummond, A.J., 2014. BEAST 2: A software platform for Bayesian evolutionary

Buerki, Sven, Lowry, P.P. II., Alvarez, N., Razafimandimbison, S.G., Küpfer, P., Callmander, analysis. PLoS Comput. Biol. 10, e1003537. https://doi.org/10.1371/journal.pcbi.1003537 M.W., 2010. Phylogeny and circumscription of Sapindaceae revisited: Molecular sequence

Buerki, S., Forest, F., Acevedo-Rodríguez, P., Callmander, M.W., Nylander, J.A.A., Harrington, data, morphology and biogeography support recognition of a new family, Xanthoceraceae. Plant Ecol. Evol. 143, 148-159. https://doi.org/10.5091/plecevo.2010.437 intricate relationships at subfamilial and tribal levels in the soapberry family (Sapindaceae). Mol. Phylogenet. Evol. 51, 238-258. https://doi.org/10.1016/j.ympev.2009.01.012

C.F. Schumacher, 1794. Om slaegten Paullinia Linn. Skr. Naturhist.-Selsk. 3, 115-132. 
species-level phylogenetics: Case study with Paullinieae (Sapindaceae). Appl. Plant Sci. 5. https://doi.org/10.3732/apps.1700051

Contreras, D.L., Duijnstee, I.A.P., Ranks, S., Marshall, C.R., Looy, C. V., 2017. Evolution of dispersal strategies in conifers: Functional divergence and convergence in the morphology of diaspores. Perspect. Plant Ecol. Evol. Syst. 24, 93-117. https://doi.org/10.1016/j.ppees.2016.11.002

Croat, T.B., 1978. Flora of Barro Colorado Island. Stanford University Press, Standford, CA.

Croat, T.B., 1976. Flora of Panama. Annals of the Missouri Botanical Garden. 63, 419-540.

Cunha Neto, I.L. Da, Martins, F.M., Somner, G. V, Tamaio, N., 2018. Successive cambia in liana stems of Paullinieae and their evolutionary significance in Sapindaceae. Bot. J. Linn.

de Candolle, A.P., 1824. Prodromus systematis naturalis regni vegetabilis. Treutel and Würtz.,

Demesure, B., Sodzi, N., Petit, R.J., 1995. A set of universal primers for amplification of polymorphic non-coding regions of mitochondrial and chloroplast DNA in plants. Mol. Ecol. 4, 129-134. https://doi.org/10.1111/j.1365-294X.1995.tb00201.X

Duan, Q., Goodale, E., Quan, R.C., 2014. Bird fruit preferences match the frequency of fruit colours in tropical Asia. Sci. Rep. 4, 5627. https://doi.org/10.1038/srep05627

Edgar, R.C., 2010. Search and clustering orders of magnitude faster than BLAST. Bioinformatics 26, 2460-1. https://doi.org/10.1093/bioinformatics/btq461 
559 Edgar, R.C., Haas, B.J., Clemente, J.C., Quince, C., Knight, R., 2011. UCHIME improves sensitivity and speed of chimera detection. Bioinformatics 27, 2194-200. https://doi.org/10.1093/bioinformatics/btr381

Erickson, H.T., Correa, M.P.F., Escobar, J.R., 1984. Guaraná (Paullinia cupana) as a commercial crop in Brazilian Amazonia. Econ. Bot. 38, 273-286.

Eriksson, O., Bremer, B., 1991. Fruit characteristics, life forms, and species richness in the plant family Rubiaceae. Am. Nat. 138, 751-761.

Fazekas, A.J., Burgess, K.S., Kesanakurti, P.R., Graham, S.W., Newmaster, S.G., Husband,

Gadek, P.A., Fernando, E.S., Quinn, C.J., Hoot, S.B., Terrazas, T., Sheahan, M.C., Chase, M.W., 1996. Sapindales: Molecular delimitation and infraordinal groups. Am. J. Bot. 83, 802-811. https://doi.org/10.2307/2445857

Gentry, A.H., 1991. The distribution and evolution of climbing plants, in: Putz, Francis E., H.A.M. (Ed.), The Biology of Lianas. Cambridge University Press, Cambridge, pp. 3-52.

Harrington, M.G., Edwards, K.J., Johnson, S.A., Chase, M.W., Gadek, P.A., Harrington, M.G., Edwards, K.J., Johnson, S.A., Chase, M.W., Gadek, P.A., 2005. Phylogenetic inference in Sapindaceae sensu lato using plastid matK and rbcL DNA sequences. Syst. Bot. 30, 366-

Herrera, M, C., 1989. Seed dispersal by animals: A role in angiosperm diversification? Am. Nat. 
Howe, H.F., Smallwood, J., 2003. Ecology of seed dispersal. Annu. Rev. Ecol. Syst. 13, 201228. https://doi.org/10.1146/annurev.es.13.110182.001221

Irvine, F.R., 1961. Woody plants of Ghana, with special reference to their uses. Oxford University Press, London.

Katoh, K., Standley, D.M., 2013. MAFFT multiple sequence alignment software version 7: Improvements in performance and usability. Mol. Biol. Evol. 30, 772-780. https://doi.org/10.1093/molbev/mst010

Klaassen, R., 1999. Wood anatomy of the Sapindaceae, IAWA Journal Supplement 2. International Asociation of Wood Anatomists, Leiden.

Koressaar, T., Remm, M., 2007. Enhancements and modifications of primer design program

Kunth, C.S., 1821. Sapindaceae in Nova Genera et Species Plantarum (quarto ed.). Lutetiae Parisiorum: sumtibus Librariae Graeco-Latino-Germanico, Paris.

Lai, Z., Lin, Y., 2013. Analysis of the global transcriptome of longan (Dimocarpus longan Lour.) embryogenic callus using Illumina paired-end sequencing. BMC Genomics 14, 561.

Lanfear, R., Frandsen, P.B., Wright, A.M., Senfeld, T., Calcott, B., 2016. PartitionFinder 2: New https://doi.org/10.1186/1471-2164-14-561

Leigh, E.G., 1999. The seasonal rythms of fruiting and leaf flush and the regulation of animal populations, in: Tropical Forest Ecology: A View from Barro Colorado Island. pp. 149-178. methods for selecting partitioned models of evolution for molecular and morphological phylogenetic analyses. Mol. Biol. Evol. 34, 772-3. https://doi.org/10.1093/molbev/msw260 
621 Magoc, T., Salzberg, S.L., 2011. FLASH: fast length adjustment of short reads to improve genome assemblies. Bioinformatics 27, 2957-2963. https://doi.org/10.1093/bioinformatics/btr507

Medeiros, H., Forzza, R.C., Acevedo-Rodríguez, P., 2016. Wild relatives of guaraná (Paullinia cupana, Sapindaceae) in southwestern Brazilian Amazon. Syst. Bot. 41, 202-228. https://doi.org/10.1600/036364416X690606

Miller, M.A., Pfeiffer, W., Schwartz, T., 2010. Creating the CIPRES Science Gateway for inference of large phylogenetic trees, in: Proceedings of the Gateway Computing Environments Workshop (GCE). 14 Nov, 2010, New Orleans, LA, pp. 1-8.

Paradis, E., Claude, J., Strimmer, K., 2004. APE: Analyses of phylogenetics and evolution in R language. Bioinformatics. https://doi.org/10.1093/bioinformatics/btg412

Blischak, P.D., Latvis, M., Morales-Briones, D.F., Johnson, J.C., Di Stilio, V.S., Wolfe, A.D., Tank, D.C., 2018. Fluidigm2PURC: Automated processing and haplotype inference for

Pellissari, L.C.O., Barros, C.F., Medeiros, H., Tamaio, N., 2018. Cambial patterns of Paullinia (Sapindaceae) in southwestern Amazonia, Brazil. Flora Morphol. Distrib. Funct. Ecol.

645 Plumier, C., 1693. Description des plantes de l'Amerique: avec leurs figures. De l'Imprimerie Royale, Paris.

648 Plumier, C., 1703. Nova plantarum americanarum genera. Apud Joannem Boudot, Paris. 
Radlkofer, L., 1933. Sapindaceae, Engler, A. (Ed.), Das Pflanzenreich IV, 165, Heft 98a-H. W. Engelmann, Leipzig, pp. 1-1539.

Radlkofer, L., 1895. Monographie der Sapindaceen-Gattung Paullinia. K. B. Akademie, Munich. https://doi.org/https://doi.org/10.5962/bhl.title.65993

Radlkofer, L., 1890. Subseries Eusapindaceae nomophyllae Tribus. Sitzungsberichte der Math. Cl. der Königl. Bayer Akad. der Wissenschaften zu München 20, 215-220.

Revell, L.J., 2012. phytools: An R package for phylogenetic comparative biology (and other things). Methods Ecol. Evol. https://doi.org/10.1111/j.2041-210X.2011.00169.x

Ronquist, F., Van Der Mark, E., Teslenko, M., Ayres, D.L., Darling, A., Höhna, S., Larget, B., Liu, L., Suchard, M.A., Huelsenbeck, J.P., 2012. Mrbayes 3.2: Efficient Bayesian phylogenetic inference and model choice across a large model space. Syst. Biol. 61, 539-

Rothfels, C.J., Pryer, K.M., Li, F.-W., 2017. Next-generation polyploid phylogenetics: Rapid resolution of hybrid polyploid complexes using PacBio single-molecule sequencing. New Phytol. 213, 413-429. https://doi.org/10.1111/nph.14111 42. https://doi.org/10.1093/sysbio/sys029

SantaLucia, J., 1998. A unified view of polymer, dumbbell, and oligonucleotide DNA nearestneighbor thermodynamics. Proc. Natl. Acad. Sci. 95, 1460-1465. https://doi.org/10.1073/pnas.95.4.1460

Schmidt, V., Schaefer, H.M., Winkler, H., 2004. Conspicuousness, not colour as foraging cue in plant animal signalling. OIKOS 106, 551-7. https://doi.org/https://doi.org/10.1111/j.00301299.2004.12769.x large phylogenies. Bioinformatics 30, 1312-1313. 
https://doi.org/10.1093/bioinformatics/btu033

Taberlet, P., Gielly, L., Pautou, G., Bouvet, J., 1991. Universal primers for amplification of three non-coding regions of chloroplast DNA. Plant Mol. Biol. 17, 1105-19. https://doi.org/10.1007/BF00037152

Tamaio, N., 2011. Wood anatomy of lianas of Sapindaceae commercially used in São Paulo - SP. Cerne 17, 533-540.

Tamaio, N., Vieira, R., Angyalossy, V., 2009. Origin of successive cambia on stem in three

R Core Development Team, 2018. R: A Language and Environment for Statistical Computing. R A Lang. Environ. Stat. Comput. R Found. Stat. Comput. Vienna, Austria. https//www.Rproject.org/.

Untergasser, A., Cutcutache, I., Koressaar, T., Ye, J., Faircloth, B.C., Remm, M., Rozen, S.G., 2012. Primer3-new capabilities and interfaces. Nucleic Acids Res. 40, e115. https://doi.org/10.1093/nar/gks596

Weckerle, C.S., Rutishauser, R., 2005. Gynoecium, fruit and seed structure of Paullinieae 159189. https://doi.org/https://doi.org/10.1111/j.1095-8339.2005.00365.x

Wu, G.A., Prochnik, S., Jenkins, J., Salse, J., Hellsten, U., Murat, F., Perrier, X., Ruiz, M., Scalabrin, S., Terol, J., Takita, M.A., Labadie, K., Poulain, J., Couloux, A., Jabbari, K.,

van der Pijl, L., 1982. Principles of dispersal in higher plants, 3rd ed. Springer, Berlin. https://doi.org/10.2307/3241400 Cattonaro, F., Del Fabbro, C., Pinosio, S., Zuccolo, A., Chapman, J., Grimwood, J., Tadeo, F.R., Estornell, L.H., Muñoz-Sanz, J. V., Ibanez, V., Herrero-Ortega, A., Aleza, P., Pérez- 
713 Pérez, J., Ramón, D., Brunel, D., Luro, F., Chen, C., Farmerie, W.G., Desany, B., Kodira,

714 C., Mohiuddin, M., Harkins, T., Fredrikson, K., Burns, P., Lomsadze, A., Borodovsky, M.,

715 Reforgiato, G., Freitas-Astúa, J., Quetier, F., Navarro, L., Roose, M., Wincker, P., Schmutz,

716 J., Morgante, M., MacHado, M.A., Talon, M., Jaillon, O., Ollitrault, P., Gmitter, F.,

717 Rokhsar, D., 2014. Sequencing of diverse mandarin, pummelo and orange genomes reveals

718 complex history of admixture during citrus domestication. Nat. Biotechnol. 32, 656-62.

719 https://doi.org/10.1038/nbt.2906 


\section{Tables}

\begin{tabular}{|c|c|c|}
\hline Radlkofer (1895; 1931) & Beck $(1991) *$ & $\begin{array}{l}\text { Sampled in this } \\
\text { phylogeny }\end{array}$ \\
\hline Paullinia sect. Neurotoechus (26) & Paullinia sect. Paullinia (19) & 14 \\
\hline Paullinia sect. Diphtherotoechus (6) & Prancea sect. Diphtherotoechus (5) & 1 \\
\hline \multirow[t]{4}{*}{ Paullinia sect. Pleurotoechus (28) } & Chimborazoa (1) & 8 \\
\hline & Prancea sect. Pleurotoechus (4) & $\mathrm{n} / \mathrm{a}$ \\
\hline & Prancea sect. Ischnotoechus (4) & $\mathrm{n} / \mathrm{a}$ \\
\hline & Timothea (3) & $\mathrm{n} / \mathrm{a}$ \\
\hline Paullinia sect. Pachytoechus (11) & Prancea sect. Prancea (21) & 2 \\
\hline Paullinia setc. Enourea (9) & Enourea (4) & 4 \\
\hline Paullinia sect. Castanella (5) & Castanella (4) & 2 \\
\hline Paullinia sect. Neuroptilon (3) & Paullinia sect. Neuroptilon (6) & 0 \\
\hline Paullinia sect. Xyloptilon (3) & & 1 \\
\hline Paullinia sect. Anisoptilon (3) & & 0 \\
\hline Paullinia sect. Isoptilon (4) & & 1 \\
\hline Paullinia sect. Caloptilon (37) & Paullinia sect. Caloptilon (48) & 11 \\
\hline Paullinia sect. Phygoptilon (12) & Paullinia sect. Phygoptilon (1) & 4 \\
\hline Paullinia sect. Cryptoptilon (1) & & 0 \\
\hline
\end{tabular}

724 Table 1. Comparison of the two major classification schemes for Paullinia. The number of

725 recognized species are in parentheses. * Beck (1991) classification of Paullinia s.s. plus five

726 smaller genera: Enourea, Castanella, Prancea, Timothea and Chimborazoa.

\section{Figure captions}

731 Figure 1. Diversity in fruit morphologies in Paullinia; plate modified from Radlkofer (1895)

732 representing his classification system. I. Section Neurotoechus, II. Section Diphtherotoechus, III.

733 Section Pleurotoechus, IV. Section Pachytoechus, V. Section Enourea, VI. Section Castanella, 
734 IX. Section Cryptoptilon, VIII. Section Neuroptilon, VII. Section Xyloptilon, X. Section

735 Anisoptilon, XI. Section Isoptilon, XII. Section Caloptilon, XIII. Section Phygoptilon.

737 Figure 2. Diversity in fruit morphologies in Paullinia. (A) dehiscent exalate fruits of $P$. imberbis

738 Acevedo 14849, (B) dehiscent alate fruits of $P$. serjaniaefolia Acevedo 7398, (C) indehiscent

739 echinate fruits of $P$. paullinoides Acevedo 14860, (D) open capsule of the dehiscent alate fruits

740 of P. caloptera Acevedo 1431, capsule open along septa to reveal black glossy seed covered by a

741 white fleshy aril. All photos by Pedro Acevedo-Rodriguez from collections.nmnh.si.edu.

743 Figure 3. Bayesian maximum clade credibility tree of the outgroup and Paullinia Clade I.

745 Figure 4. Bayesian maximum clade credibility tree of Paullinia Clades II, III, IV and V.

747 Figure 5. Bayesian maximum clade credibility tree of Paullinia Clades VI and VII.

749 Figure 6. Ancestral state estimations of fruit morphology on the Paullinia maximum clade credibility tree. 
bioRxiv preprint doi: https//doi.org/10.1101/673988; this version posted June 19, 2019. The copyright holder for this preprint (which was not

Figure 1

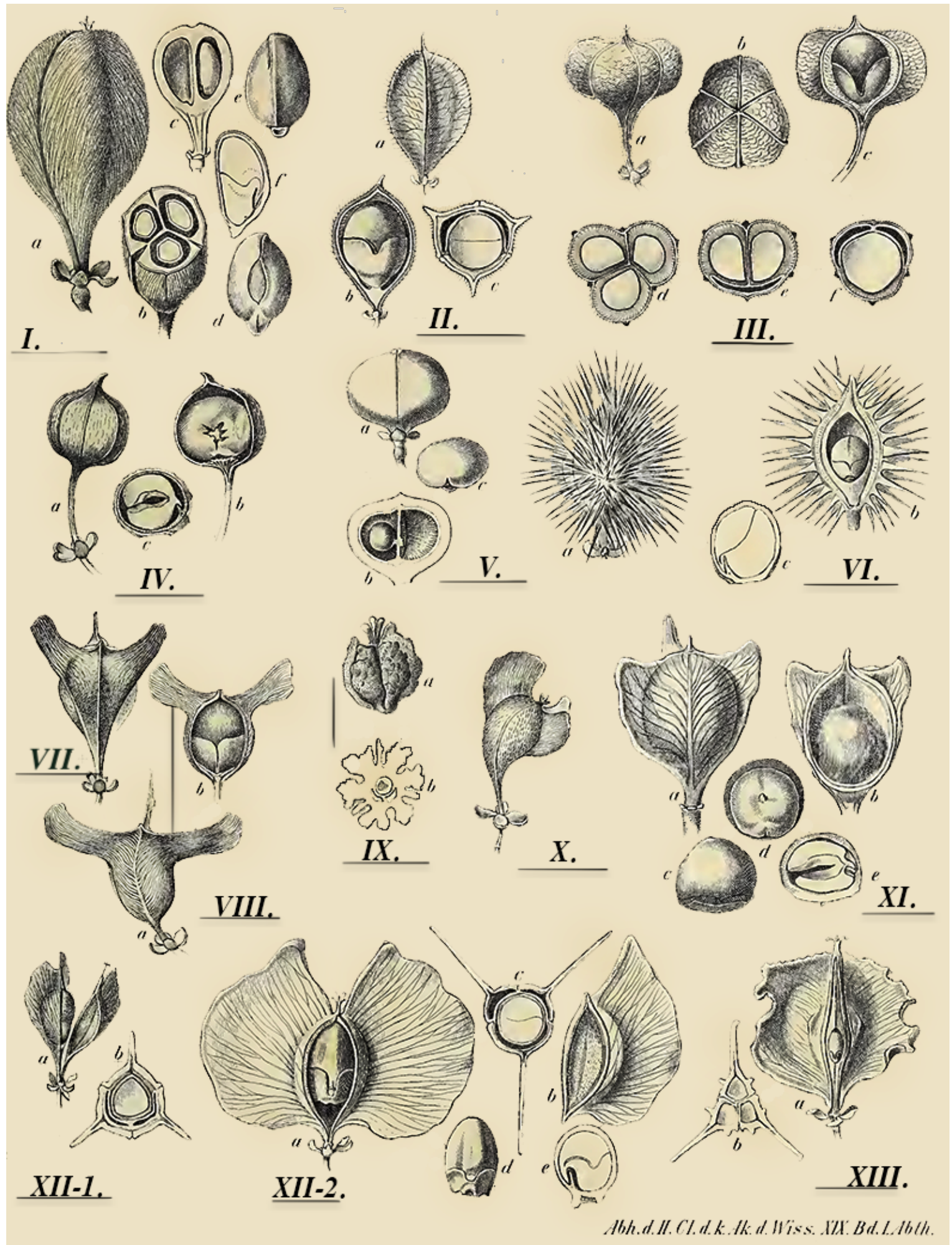


bioRxiv preprint doi: https://doi.org/10.1101/673988; this version posted June 19, 2019. The copyright holder for this preprint (which was not certified by peer review) is the author/funder, who has granted bioRxiv a license to display the preprint in perpetuity. It is made available under aCC-BY-ND 4.0 International license.

Figure 2

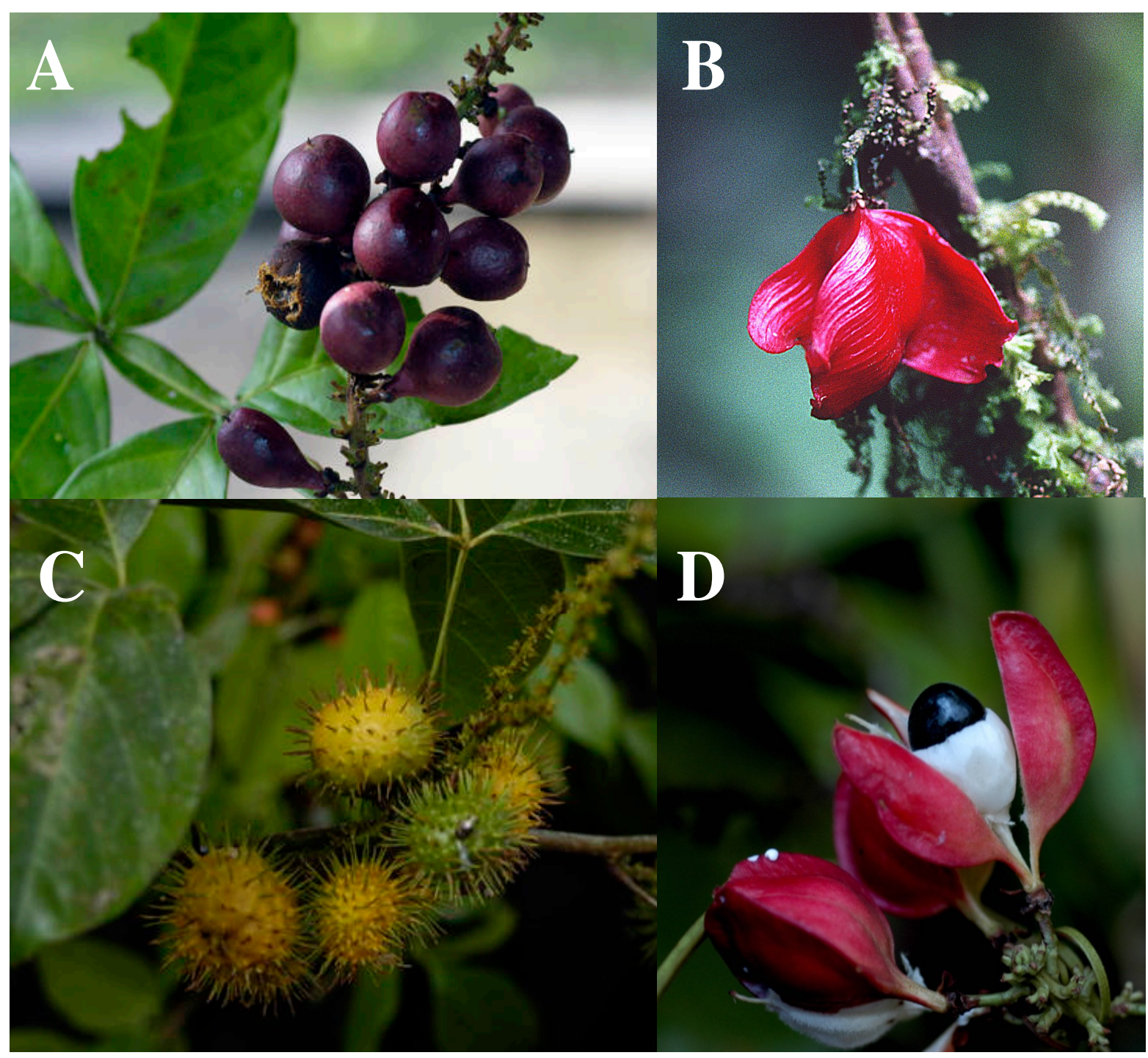


bioRxiv preprint doi: https://doi.org/10.1101/673988; this version posted June 19,2019. The copyright holder for this preprint (which was not certified by peer review) is the author/funder, who has granted bioRxiv a license to display the preprint in perpetuity. It is made available under aCC-BY-ND 4.0 International license.

Figure 3

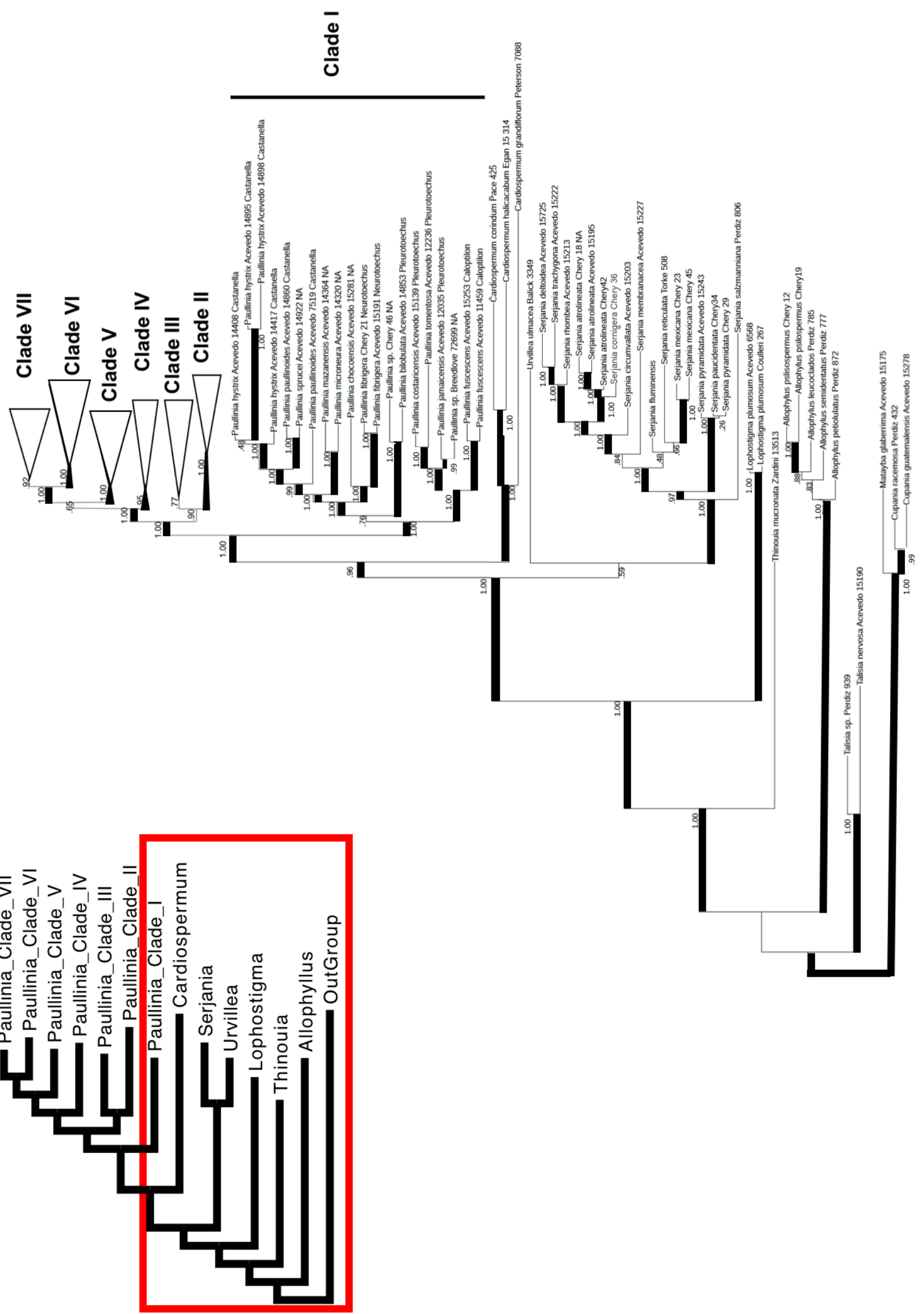


bioRxiv preprint doi: https://doi.org/10.1101/673988; this version posted June 19, 2019. The copyright holder for this preprint (which was not certified by peer review) is the author/funder, who has granted bioRxiv a license to display the preprint in perpetuity. It is made available under aCC-BY-ND 4.0 International license.

Figure 4
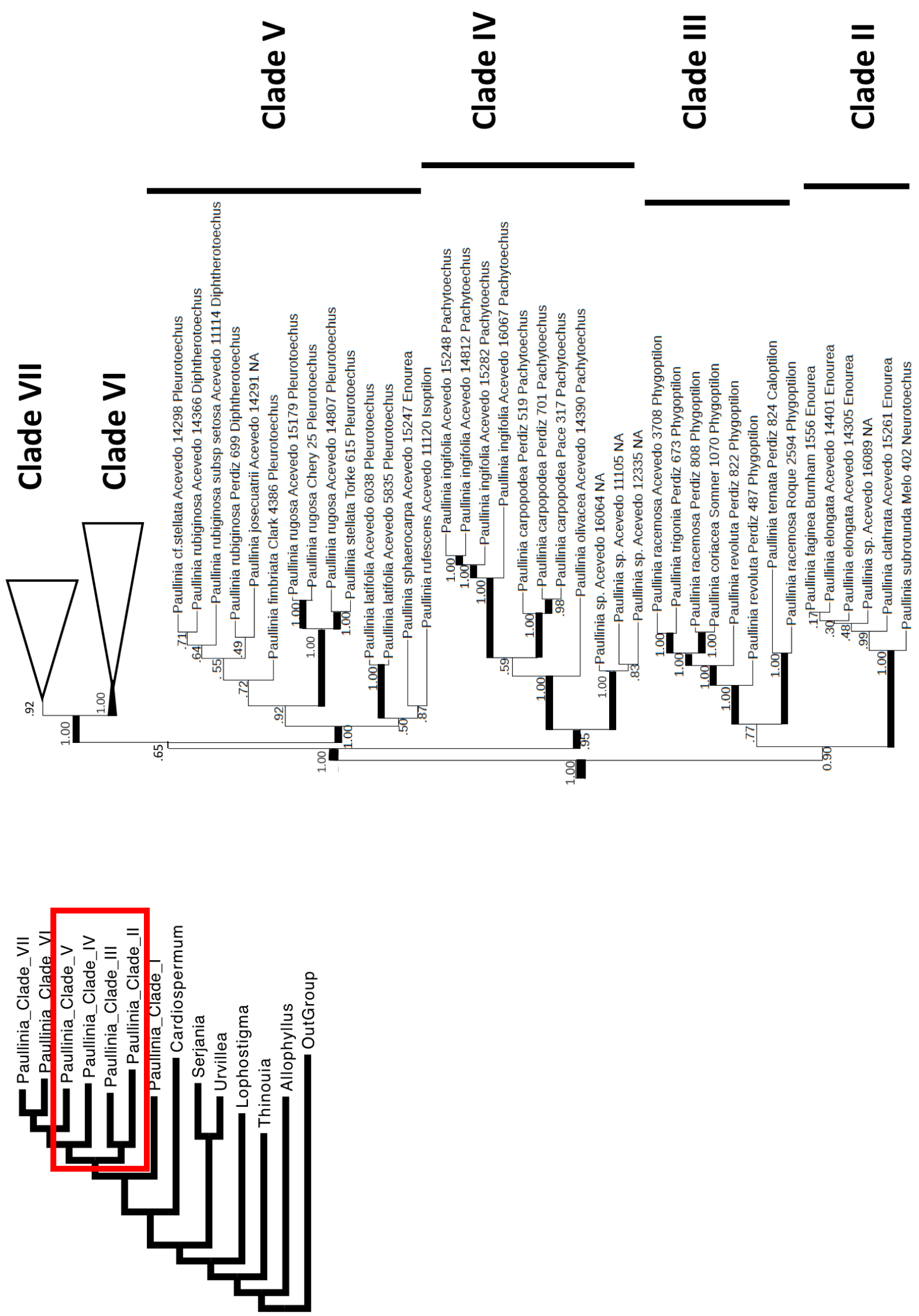
bioRxiv preprint doi: https://doi.org/10.1101/673988; this version posted June 19 2019. The copyright holder for this preprint (which was not certified by peer review) is the author/funder, who has granted bioRxiv a license to display the preprint in perpetuity. It is made available under aCC-BY-ND 4.0 International license.

Figure 5
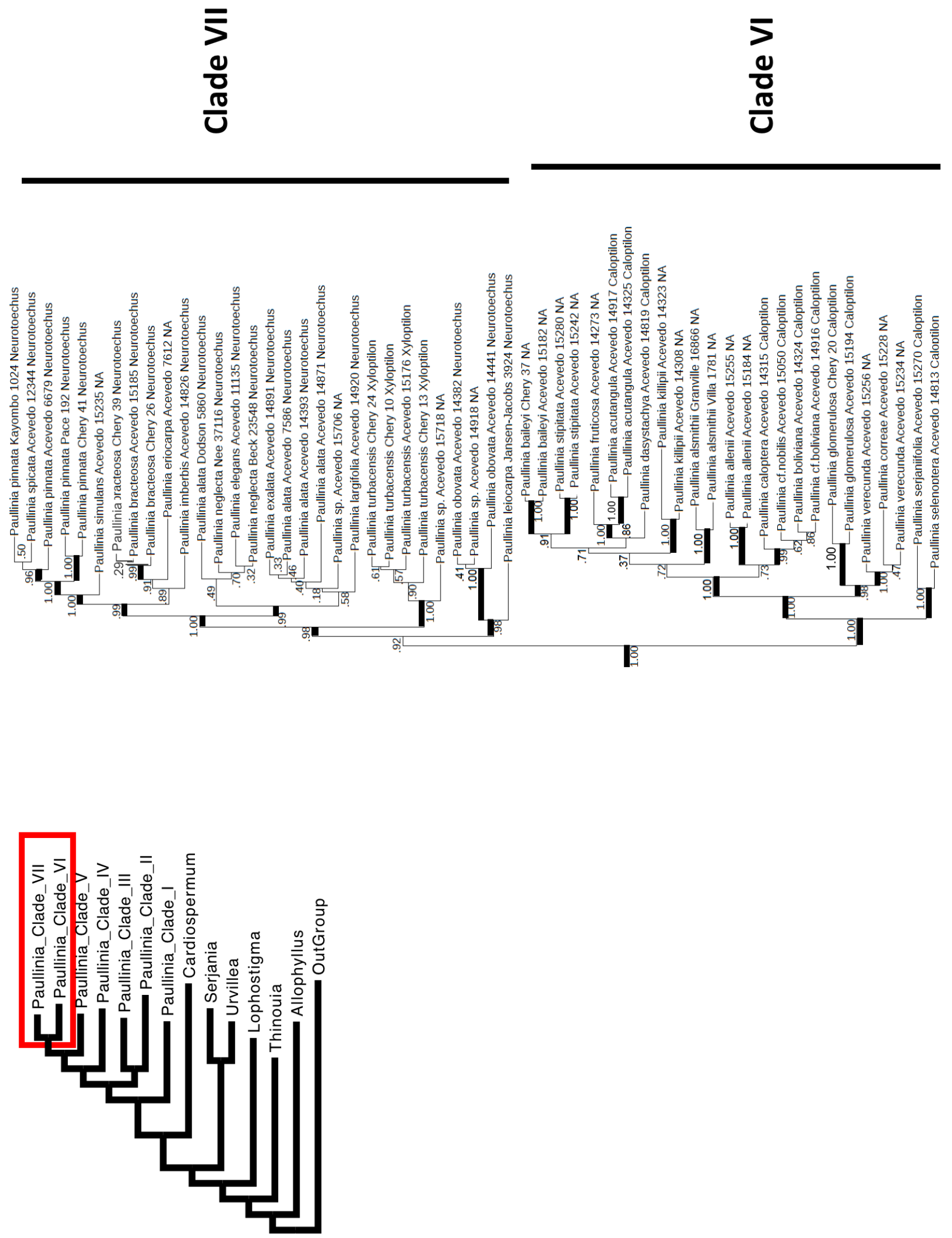
bioRxiv preprint doi: https://doi.org/10.1101/673988; this version posted June 19, 2019. The copyright holder for this preprint (which was not certified by peer review) is the author/funder, who has granted bioRxiv a license to display the preprint in perpetuity. It is made available under aCC-BY-ND 4.0 International license.

Figure 6

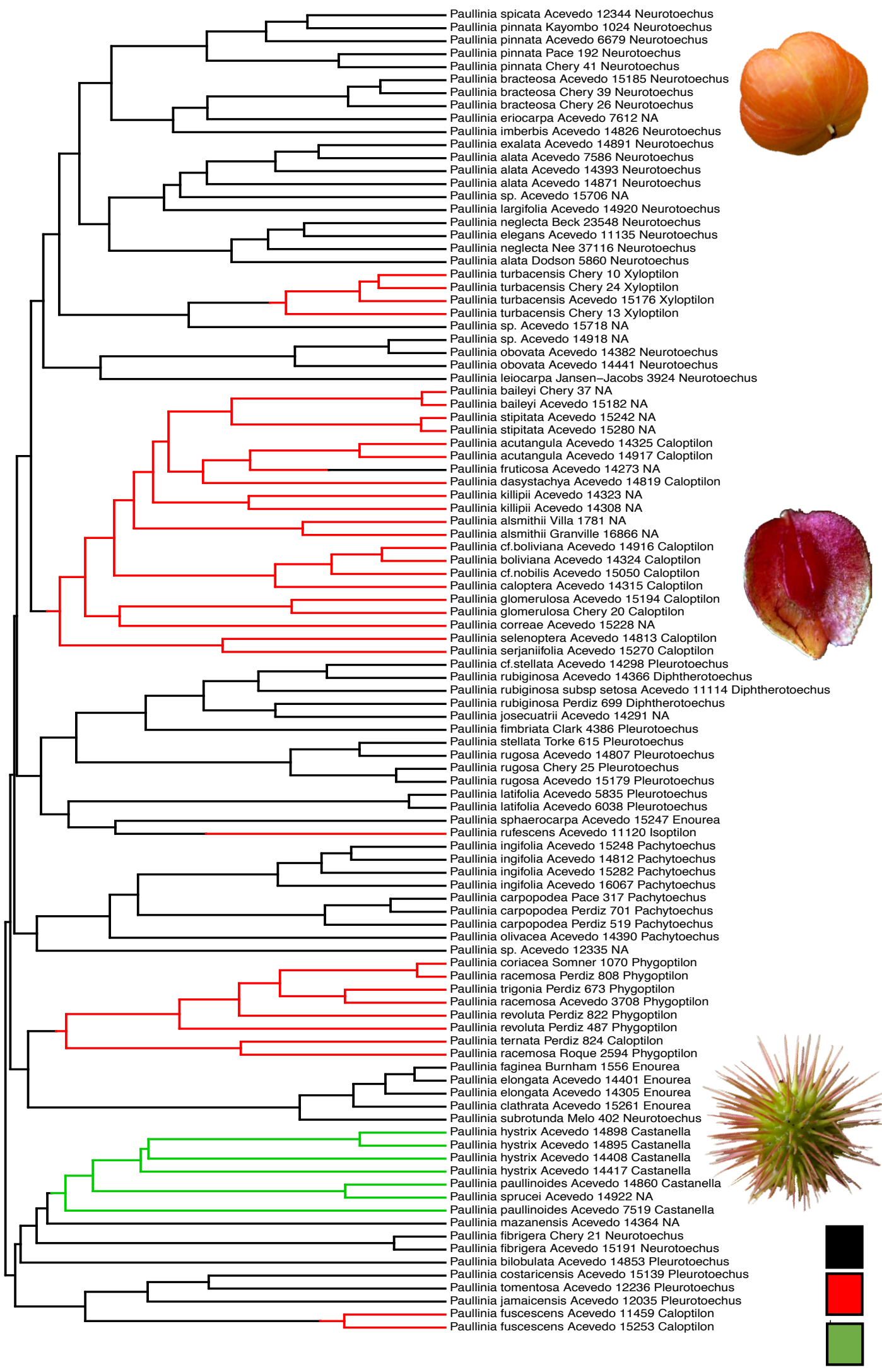

=exalate =alate =echinate 